\title{
Fana 'As Stress Therapy According To Al-Ghazali Through Kitab Al-Arba'in Fi Usul Al-Din
}

Adam N. S., Omar S. H. S., Baru R., Ali M. S., Ismail M.S., Zin E. I. E. W., \& Mat@Mohamad M. Z.

To Link this Article: http://dx.doi.org/10.6007/IJARBSS/v10-i11/8207

DOI:10.6007/IJARBSS/v10-i11/8207

Received: 07 September 2020, Revised: 11 October 2020, Accepted: 13 November 2020

Published Online: 29 November 2020

In-Text Citation: (Adam et. al., 2020)

To Cite this Article: Adam, N. S., Omar, S. H. S., Baru, R., Ali, M. S., Ismail, M. S., Zin, E. I. E. W., \& Mat@Mohamad, M. Z. (2020). Fana 'As Stress Therapy According To Al-Ghazali Through Kitab Al-Arba'in Fi Usul Al-Din. International Journal of Academic Research in Business and Social Science, 10(11), 1282-1288.

Copyright: @ 2020 The Author(s)

Published by Human Resource Management Academic Research Society (www.hrmars.com) This article is published under the Creative Commons Attribution (CC BY 4.0) license. Anyone may reproduce, distribute, translate and create derivative works of this article (for both commercial and non-commercial purposes), subject to full attribution to the original publication and authors. The full terms of this license may be seen at: http://creativecommons.org/licences/by/4.0/legalcode

Vol. 10, No. 11, 2020, Pg. 1282 - 1288

Full Terms \& Conditions of access and use can be found at http://hrmars.com/index.php/pages/detail/publication-ethics 


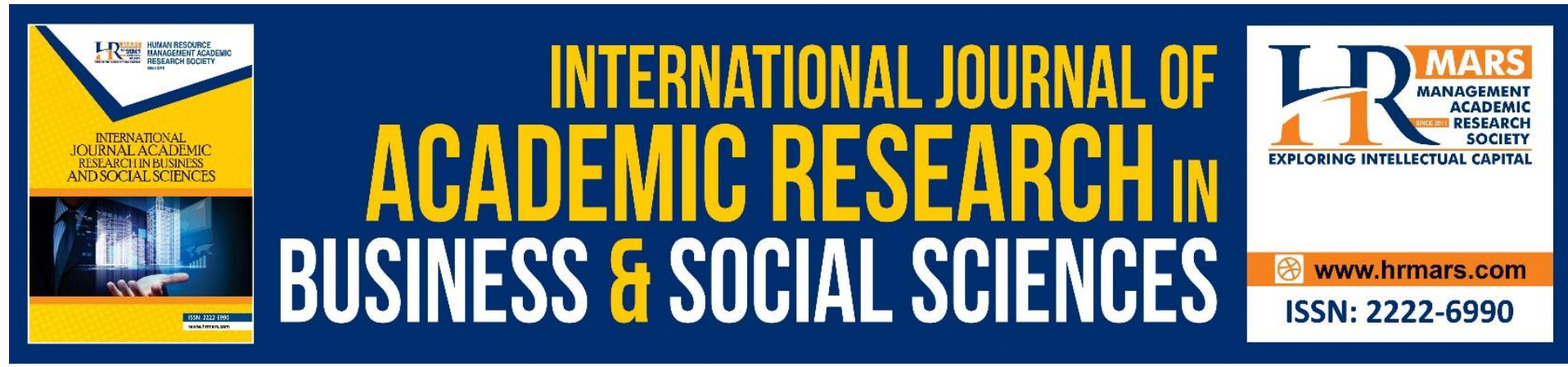

\title{
Fana 'As Stress Therapy According To Al-Ghazali Through Kitab Al-Arba'in Fi Usul Al-Din
}

\author{
${ }^{1}$ Adam N. S., ${ }^{2}$ Omar S. H. S., ${ }^{2}$ Baru R., ${ }^{2}$ Ali M. S., ${ }^{2}$ Ismail \\ M.S., ${ }^{2}$ Zin E. I. E.W., \& ${ }^{2}$ Mat@Mohamad M. Z. \\ ${ }^{1} \mathrm{PhD}$ Candidate, Faculty of Islamic Contemporary Studies, ${ }^{2}$ Faculty of Islamic \\ Contemporary Studies, Universiti Sultan Zainal Abidin (UniSZA), Terengganu, Malaysia.
}

\begin{abstract}
Fana' according to the discipline of Sufism is a spiritual experience referring to the focus of strong memory only on the greatness and majesty of Allah SWT and blunt memory of other things. It is further strengthened by the fading feeling of dependence on anything other than Allah SWT. This study aims to analyse the concept of fana' found in the discipline of Sufism and its ability to reduce the stress encountered by individuals in the Muslim community today based on the spiritual theory of al-Ghazali. This qualitative study uses the method of data collection by making the works that have been produced by al-Ghazali as the main reference in addition to expert interviews of related issues. All data obtained were analysed to produce research findings. Studies have found that the concept of fana' according to al-Ghazali is the ability to reduce the stress faced by individuals. This is because, the ability of the individual to maintain the memory of the heart only to Allah SWT, could eliminate the stress feelings that strike within. Study concludes that the concept of fana' has positive implications in daily life that serve as spiritual therapy in reducing stress.
\end{abstract}

Keywords: Fana, Al-Ghazali, Sufism, Stress, Spiritual Therapy.

\section{Introduction}

The concept of fana' is one of the various concepts found in the discipline of Sufism. This concept is not a stranger according to the views of Sufi figures because it is considered as an important instrument to achieve the maqam ma'rifah Allah SWT. Examining the literature review, most focus on the study of the views expressed by certain figures on the concept of fana' (Yunan, 2009; Mahmuddin, 2010; Khairi, 2015) while highlighting discussions around the deviation of Sufi practices related to this concept (Ibn-Idris, 1999). Observing various definitions of the concept of fana' that have been presented in the work of Sufism (Is'ad, 1974; al-Ghazali, 1988; al-Qushayri, 1989; al-Kalabazi, 1994; Ibrahim, 1999), fana' can be formulated as a spiritual experience focusing strong memory of the greatness and majesty of Allah SWT. This is further strengthened by the loss of feelings of dependence on something other than Allah SWT. In practical application, it can be understood that the concept of fana' experienced is able to eliminate the focus of Sufis on the state of the environment, so that every problem that befalls in life can be seen from a positive perspective and conviction that it will find its solution with the permission of Allah SWT. 
This article attempts to examine the concept of fana' found in the discipline of Sufism and its ability to reduce the stress faced by individuals in the Muslim community today. This is because, most past works of Sufism focus on the study around the views of prominent figures on this concept without discussing its implications in the reality of life. Specific interviews with Sufi practitioners on the East Coast of Peninsular Malaysia were conducted to identify the extent to which the concept of fana' that has been understood can have an impact in life. In this regard, this article attempts to evaluate the views of the Sufi practitioners on its effect in reducing stress.

\section{Research Methodology}

To achieve the research objectives, the method of document analysis has been used by making the work of al-Ghazali, al-Arbai'n Fi Usul al-Din as the main reference. In addition, interviews with several expertise in Tasawuf around the East Coast of Peninsular Malaysia were also conducted. All data collected including the data in the form of interview transcripts were analysed using content analysis methods.

\section{Fana' in Al-Ghazali's Perspectives}

In the context of practicing the value of Sufism, al-Ghazali has made maqam fana' as an instrument to achieve the ma'rifah Allah SWT. In addition, he has the same view as the other prominent Sufi figures which ma'rifah Allah is the last maqam that the salik will have to pass in achieving the gratification of Allah SWT (al-Ghazali, 1988; Idris, 1999). In this regard, alGhazali also explained that the highest spiritual experience, which can be achieved in the practice of the Sufi practitioner is when the consciousness of memory (fana') is lost to all beings in the heavens and the earth except Allah SWT. This condition is also termed with ma'rifah Allah by him (al-Ghazali, 1988; Chatib, 1996).

In addition, al-Ghazali also uses the term istighraq which also refers to the meaning of $f a n a^{\prime}$. In this regard, he has stated that the testimony of the greatness of Allah SWT does not occur in the naked eyes of the salik who is experiencing a state of fana'. On the other hand, this experience can only be felt through the spiritual view (al-Ghazali, 1988; Maimunah, 2008).

\section{Definitions and Causes of Stress}

In general, stress is a response associated with the emotional (psychological) and physical of an individual as a result of the living environment. These symptoms occur due to the emotional inability to accept the stress or changes that occur around. This situation also gives a change to the actions of people who experience it. However, stress that is still under control can motivate an individual to achieve goals in life. If left unchecked, stress can have negative implications in a person's life (Abidin, 2009; Australian Psychological Society, 2012; Michie, 2017).

Symptoms of stress include fatigue, headache, irritability, restlessness, sleep disturbances, changes in appetite and aggressive behaviour, extreme anxiety and depression, drug and alcohol abuse, accidents, chest pain, headache, weakening the body's immune system in fighting infections, exhaustion and so on (Zafir, 2010; Michie, 2017; Ministry of Health Malaysia, 2017). 
According to Abidin. (2009), stress symptoms can be divided into six stages:

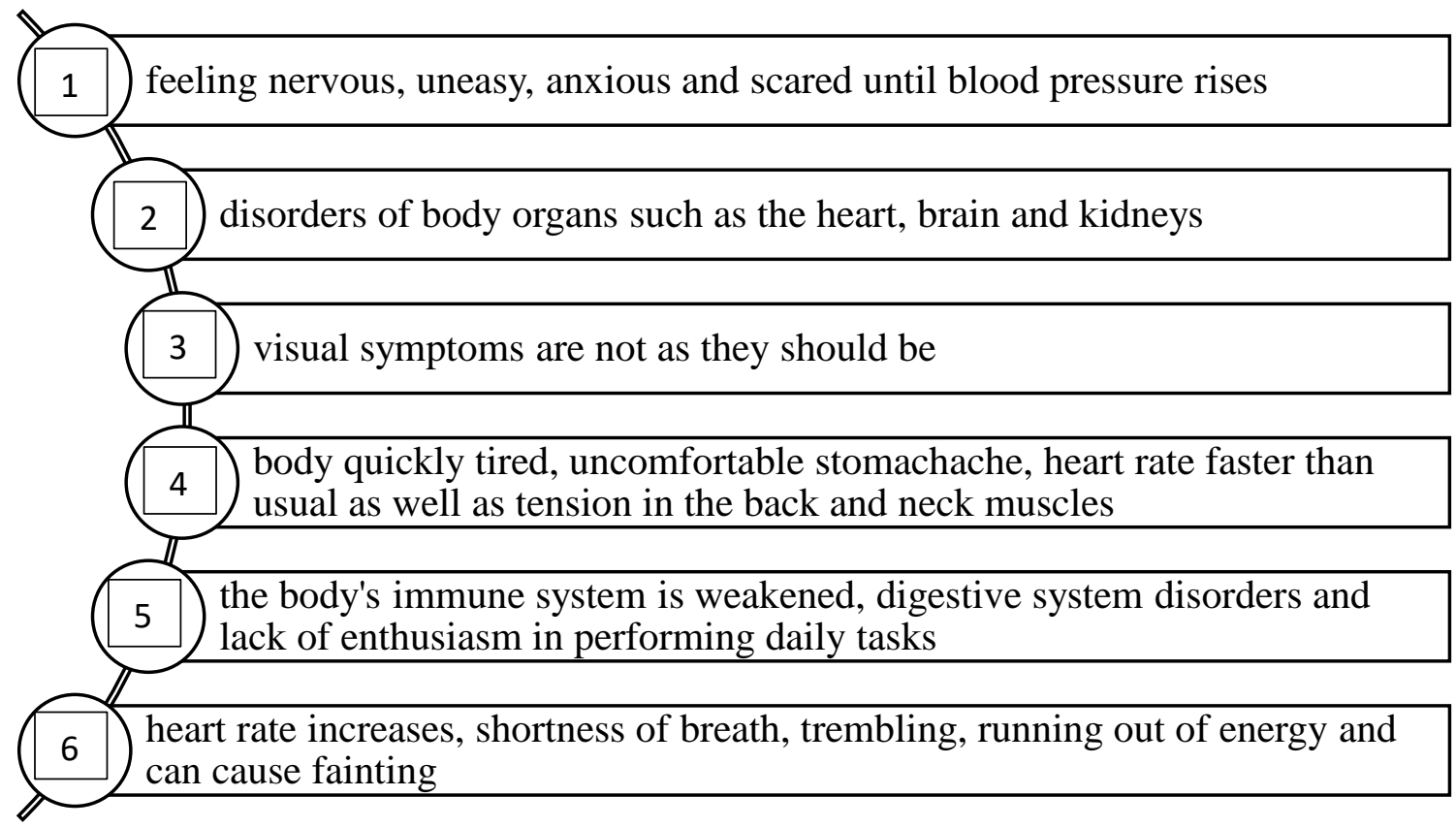

Based on the statement of the Ministry of Health Malaysia (2017), stress can occur due to several factors. Among them, high self-expectation that is too high to be achieved in a certain period of time. In addition, stress is also caused by conflicts that occur in a household due to finance, tragedy, workload and conflict among colleagues (Ministry of Health Malaysia 2017). Meanwhile, according to Noorsyafenas \& Yunus (2006), stress may also be caused by social life in the current modern time such as the use of vehicles, computers, mobile phones and so on. In addition, not believing in qaḍ' and qadar, relying too much on human beings instead of Allah SWT and difficulty to forgive the mistakes of others is also a source of stress.

Even so, from an Islamic perspective, the main cause of stress in an individual's life is due to the state of the heart which is distant from Allah SWT (Norhafizah \& Zarrina, 2017). In this regard, al-Ghazali has outlined ten spiritual heart diseases that need to be purified in order to be free from stress. The ten traits are greed in eating, greed in speaking, anger, jealousy, stinginess and love of wealth, love of luxury, love of the world, arrogance, pride and proud (al-Ghazali, 1988; Hadzrullathfi et. al, 2009). If these characters can be removed, if these negative traits cannot be purified from the heart, the individual involved will feel this world is insignificant because of no place to depend on and every problem that befalls seems to have no way out. Based on this discussion, the cause of stress is divided into four parts, namely: 
Figure 1: Causes of Stress

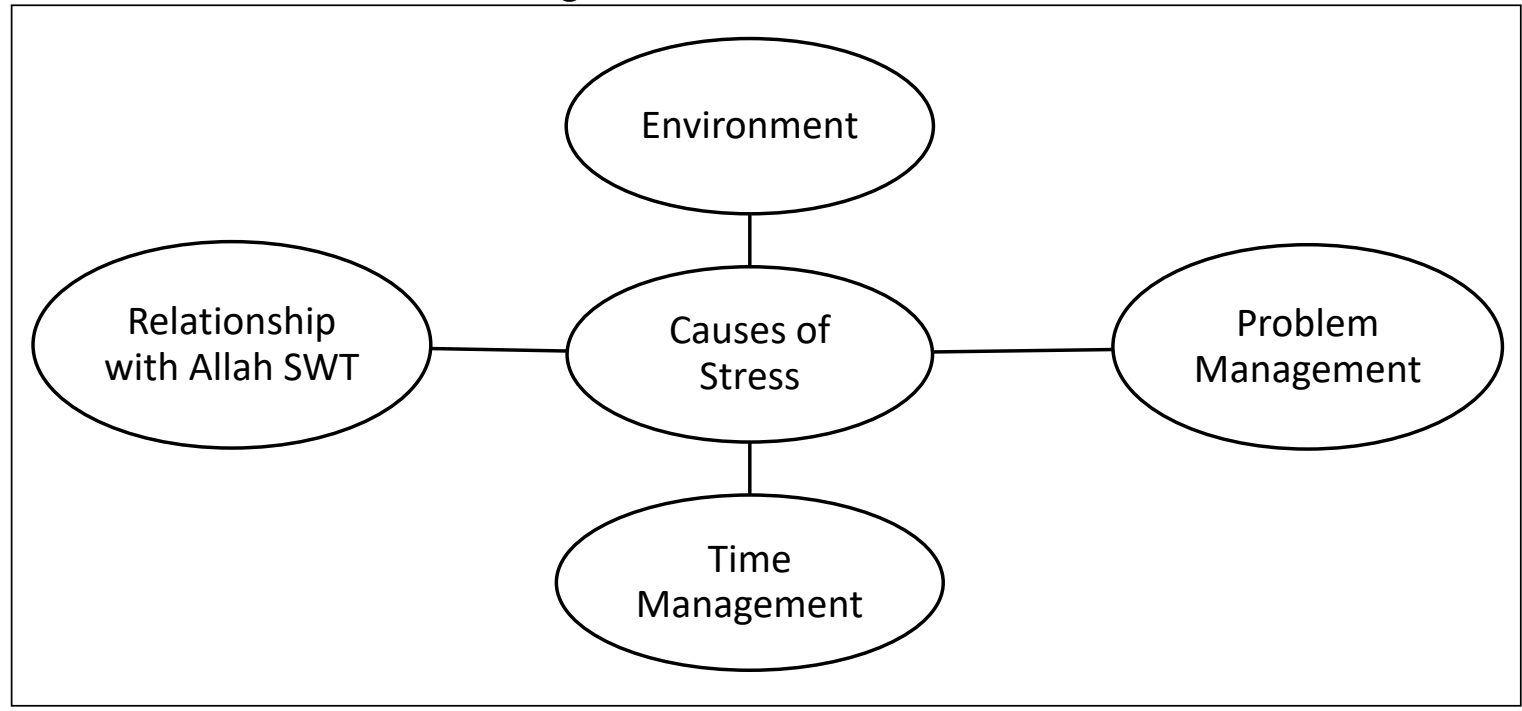

Fana' Instrument to Reduce Stress in Al-Ghazali's Spiritual Theory

Based on psychological methods, there are ten important steps that are recommended to reduce stress, namely gratitude, talking to oneself, breathing regularly, worshiping, resting and massaging, sharing feelings, leisure, listening to music, positive thinking and exercise (Ministry of Health Malaysia, 2017). However, based on the views of Sufi scholars, especially al-Ghazali, stress is a disease related to the soul that stems from al-aghyar (things other than Allah) is rooted in the heart and eventually it gives rise to various negative traits, some of which are stress problems (al-Ghazali, 1988). In the discipline of Sufism, there are several instruments to reduce stress and among them are mainly dhikr and tafakkur (Noorsyafenas \& Yunus, 2006).

Fana' according to al-Ghazali (1988) is a change in the feelings of the heart that occurs as a result of continuous memory that exists in the heart. Therefore, according to him, the process of producing fana' is necessarily through the practice of dhikr to remember Allah SWT. However, the practice of dhikr is necessary through four stages. The first stage, the act of dhikr is done orally. In other words, the verbal pronunciation of dhikr without contemplation of its meaning is not easy to eliminate stress disorders in a person's feelings.

Therefore, one needs to do dhikr in the second stage, which is to say the word dhikr in the heart and meditate on its meaning. In this second stage, one has to force oneself to present the memory of the meaning while remembering the greatness and majesty of Allah SWT. At that moment, the feeling began to gradually replace the emotional stress that first settled in the heart. However, al-Ghazali (1988); Cholevas (2013) asserted that the sense of greatness and majesty of Allah will not last because at this stage, a person is very dependent on the strength of memory to present the meaning of dhikr performed forcibly. When the practitioner no longer concentrates on the meaning of the dhikr, then stress slips back into his emotions causing him to be as disturbed as before. Such person needs a third level of $d h i k r$ and contemplation.

In the third stage, the practitioner who recites dhikr in the heart, is able to easily present the meaning contained in it. That is, the memory of a person who recites dhikr at that 
time will only focus on the meaning of the greatness and majesty of Allah in addition to the practitioner himself trying to dispel any form of memory crossed that is other than Allah SWT. At this point, presenting the memory to the meaning of dhikr mentioned in the heart is no longer a difficulty for him, in fact it becomes ingrained in him which is quite difficult to separate from him. Individuals who have this level of remembrance, are able to ward off various forms of feelings that invite stress towards themselves.

Al-Ghazali suggested that the fourth stage of remembrance is the best level for an individual to have. Stage four means that the practitioner only needs to focus on the meaning of dhikr without mentioning the dhikr in the heart. At this stage, only the focus on the meaning of the greatness and majesty of Allah SWT is done by the practitioner. This process is also termed in the discipline of Sufism as muraqabah. In other words, the practitioner at that time was able to feel the greatness and majesty of Allah SWT without having to force himself to say the dhikr in the heart. This ultimately endorses the greatness and majesty of Allah SWT alone which only feels to exist in the heart so that the memory for oneself also becomes blunt. This experienced situation is termed by Sufi scholars as fana'. As a result, a person is able to make his heart free from the shackles of being and indirectly able to relieve stress completely.

Figure 2: Stress Management Process Based on al-Ghazali's Spiritual Theory

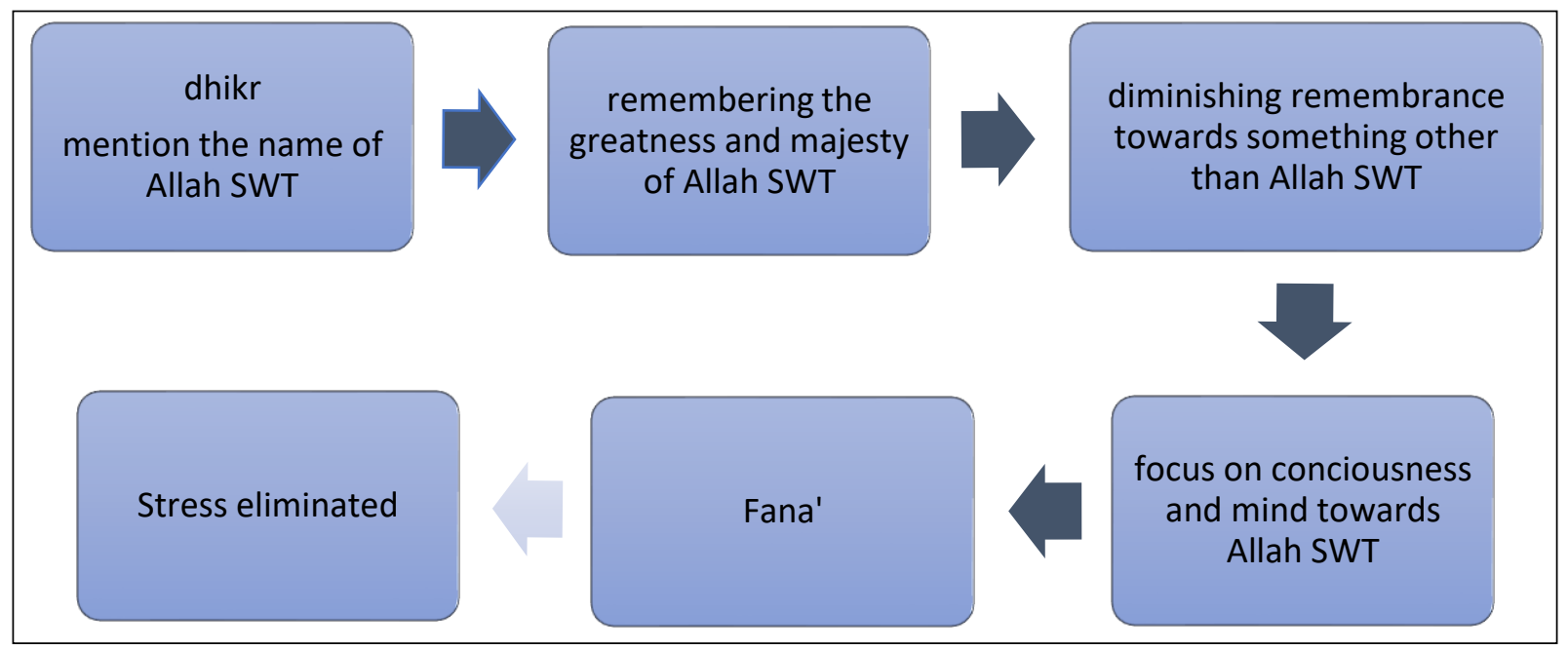

\section{Conclusion}

In conclusion, the feeling of stress that envelops the life of the individual can be eliminated from the heart if there is another conscious memory that is stronger and becomes the focus for him. The concept of fana' in al-Ghazali's spiritual theory refers to the focus of the consciousness of the memory of the heart only on Allah SWT to the point of blinding all the consciousness of memories and feelings towards His created beings. The fana' theory put forward is found to be able to relieve and also eliminate the feeling of stress experienced by individuals when the techniques and methods outlined can be grasped perfectly.

\section{Acknowledgement}

This article is part of research sponsored by the Center for Research Excellence and Incubation Management (CREIM), Sultan Zainal Abidin University (UniSZA), Gong Badak Campus 21300 Kuala Nerus, Terengganu, Malaysia. 


\section{Corresponding Author}

Email: sylutfi@unisza.edu.my

\section{References}

Mohamad, A. M. (2016). Fana' pada Pandangan Tokoh Tarekat di Pantai Timur. (Nur Syazana Adam, interviewer).

Al-Bukhari, A. B. M. I. (1994). al-Ta'rif li Mazhab Ahl al-Tasawwuf. Keherah: Maktabah alKhanuji.

Al-Ghazali, A. H. (1988). Ihya' Ulum al-Din. Kaherah: MArkaz al-Ahram li al-Tarjamah wa alNashru.

Al-Qari, I. I. (1999). The Secret of Sufi . Kuala Lumpur: Jasmin Enterprise.

Yasin, I. I. (1999). Hal Fana' fi al-Tasawwuf al-Islami. al-Mansurah: Dar al-Ma'arif.

Al-Hadi, I. Q. (1974). Kasyfu al-Mahjub li al-Hujwiri (Jil. 2). Iskandariyyah: Maktabah alIskandariyyah,

Quzwain, M. C. (1996). Mengenal Allah. Batu Caves: Thinkers Linrary Sdn. Bhd.

Mahmuddin. (2010). Pemikiran Abu Yazid Albustami Tentang Fana, Baqa Dan Ittihad dalam Jurnal al-Fikr, 58-63.

Mahyuddin, M. K. (2015). The Tawhidic Concept and the Practices of the Naqshabandiah Mujaddidiah Ahmadiah Order According to Wan Sulaiman Wan Sidek . PhD Thesis, Bangi: t.d.t.

Butar, M. Y. (2009). Doktrin Fana' Menurut Pemikiran 'Ain al-Qudat al-Hamadani . Yogyakarta: Universitas Islam Negeri Sunan Kalijaga.

Cholevas, N. K. (2013). The Role of the School in the Deconstruction of Stereotypes and Prejudice: Outline of a Program Design on the Topic "We Embrace Cultural Diversity through Literature". Multilingual Academic Journal of Education and Social Sciences, $1(2), 107-122$.

Musa, N., Sa'ari, C. Z. (2017). Teori Psikoterapi Islam Dalam Menangani Stres. S Michie. "Causes And Management Of Stress At Work." Occup Environ Med 2002, July 2017: 67-72.

Safe, S. N., \& Nor, A. Y. M. (2006). Pengurusan Stres Menurut al-Quran dan Hadith dalam Jurnal al-Hikmah, 8 (1) 3-18.

Omar, S. H. S., Zin, E. I. E. W., Othman, M. S., \& Musa, R. (2009). Dhikr Ism al-Dhat: Tuntutan Amalannya Dalam al-Quran." Jurnal Islam dan Masyarakaat Kontemporari, 2009: 5568.

Omar, S. H. S. (2016). Fana' pada Pandangan Tokoh Tarekat di Pantai Timur. (Nur Syazana binti Adam, interviewer).

Makhbul, Z. M. (2010). Benarkah Stres Mengancam Kualiti Kehidupan? dalam Prosiding Bengkel Pemantauan Dan Pembentangan Output Penyelidikan. Bangi: Fakulti Ekonomi dan Pengurusan, Universiti Kebangsaan Malaysia, 41-51. 